\author{
WIMAL HEWAMANAGE, \\ University of Colombo (Colombo, Sri Lanka) \\ e-mail:wimal@bs.cmb.ac.lk,ORCID0000-0003-2886-7637
}

\title{
EXAMINATION OF THE NOBLE TRUTHS IN THE MÜLAMADHYAMAKAKĀRIKĀ AND ITS RELEVANCE TO EARLY BUDDHISM
}

The article is devoted to an insufficiently explored page of history of early Buddhist philosophy, namely, the formation of the Noble Truths doctrine in the work of Nāgārjuna, the famous Indian philosopher of the II-III centuries AD, who is considered the founder of the Mādhyamaka school of Mahāyāna philosophy. An important source of this branch is the Mūlamadhyamakakārikā, or the "Fundamental Verses on the Middle Way", compiled by Nāgārjuna. This book consists of 27 sections and is considered the basic text of the Mahāyāna, which had a great influence on further evolution of Buddhist philosophy in India, Tibet and East Asia. The article analyzes the $24^{\text {th }}$ section "The Noble Truths Study", which consists of $\mathbf{4 0}$ verses devoted to various issues on the conditions for learning the truth. The purpose of this article is to analyze the substantive issues of $24^{\text {th }}$ section in the context of unfolding of early Buddhist philosophical discourse. Nāgārjuna's views on the ways of achieving truth are compared with the interpretations of modern historians of Buddhist philosophy: D. Kalupahana, A. Tillakaratne, M. Siderits, S. Katsura and others. Given comparativistics allow us to understand more comprehensively Mahāyāna's process of formation, as well as to provide a meaningful explanation of what the Sūnyatā is.

Key words: Buddhist philosophy; Nāgārjuna; Mūlamadhyamakakārikā; Mahāyāna; Sūnyatā.

\section{Introduction}

The Mūlamadhyamakakārikā which was composed by Nāgārjuna, a great Buddhist philosopher with 27 chapters is an everlasting text on Buddhist philosophy. The $24^{\text {th }}$ chapter 'Examination of the Noble Truths' consists with 40 verses and 27 chapters focusing on various topics expressing Examination of Conditions, Examination of the Āyatanas, Examination of the Skandhas, Examination of the Dhātus, Examination of the Conditioned, Examination of Object and Agent, Examination of What Is Prior, Examination of Fire and Fuel, Examination of Suffering etc. Aim of this paper is to investigate the subject matters in the $24^{\text {th }}$ chapter and its relevance to early Buddhist discourses. This comparison helps us to rethink about the consideration of Nāgārjuna as Mahayanist and also the most meaningful interpretation on what śunyatā is. In this regard research made by many scholars should be highly appreciated. Among those Mūlamadhyamakakārikā of Nāgārjuna: The Philosophy of the Middle Way, Nāgārjuna's Moral Philosophy and Sinhala Buddhism composed by Devid J. Kalupahana, Nāgārjuna's Middle Way Mūlamadhyamakakārikā composed by Mark Siderits and Shōryū Katsura and one of the Sinhala version of the Mūlamadhyamakakārikā with translation and remarkable critique named Śūnyatāvādayehi Darњnaya ha Carañaya: Nāgārjuna Pādayange Mūlamadhyamakakārikāvehi Pela, Sinhala Parivartanaya hā Artha Vivarañaya was written by Asanga Tilakaratne are highly appreciated.

Examination of the Noble Truths

As mentioned above this is the $24^{\text {th }}$ chapter which consists with 40 verses and is the longest among all chapters. This is the area where Nāgārjuna directly discusses fundamental point of his philosophy, emptiness since text does not allocate a separate chapter for the concept of emptiness. There are few classifications made by scholars on 27 chapters of the Mūlamadhyamakakārikā. Kalupahana categorizes into four sections; first and second chapters for the most fundamental doctrines of Buddhism, causation and change, $3^{\text {rd }}-15^{\text {th }}$ chapters for non-substantiality of the phenomena (dharmanairātmya), $16^{\text {th }}-26^{\text {th }}$ chapters for non-substantiality of the individual (pudgalanairātmya) and while the last chapter is the fourth section it is the summery of the text. Third section consists with the most confusion chapters in the mind of many who write on thought of Nāgārjuna (Kalupahana 1986: 29). Kris Linditner categorizes under eight sections and the $24^{\text {th }}$ chapter is included into the seventh section, form $22^{\text {nd }}-25^{\text {th }}$ chapters. Since this section demonstrates sacred concepts of Buddhist thought it has been separately categorized (Tilakaratne 2001: 14, 15). This explanation shows that how this chapter is significant to investigate the Buddhist teachings.

In brief the chapter is composed as a discussion with rivals who are against Nāgārjunana's philosophy of emptiness. To refute rival argument, Nāgārjuna expressed the notion of double truths, emptiness and self-nature. Rival's arguments are as follows; "If all this is empty, then there exists no uprising and ceasing. These imply the non-existence of the four noble truths. In the absence of the four noble truths, understanding, relinquishing, cultivation, and realization will not be appropriate. In the absence of this [fourfold activity], the four noble fruits would not be evident. In the absence of the fruits, neither those who have attained the fruits nor those who have reached the way [to such attainment] exist. When the doctrine and the congregation are non-existent, how can there be an enlightened one? Speaking in this manner about emptiness, you contradict 
the three jewels, as well as the reality of the fruits, both good and, all such worldly conventions" (Kalupahana, 1983: 326-330). Starting with 'all this is empty' these six verses highlighted meaningless and illogical nature of the concept. It argues gradually non existence of uprising and ceasing to result of good and bad actions and all worldly conventions. During this argument even emptiness is also refuted. These calumnies which were raised to Nāgārjuna were derived from the Sarvātivādins, substantialists as interpretations of Kalupahana (Kalupahana, 1983: 327).

\section{Concept of double truths}

To answer these calumnies Nāgārjuna's theoretical point is emptiness but it goes under three parts conventional and ultimate truths, dependent origination and self-nature. Nevertheless all those facts frankly point out the notion of emptiness (śunyatā) which was the most popularized notion of his teachings. At the very first, he expresses the concept of double truths; the Buddha's teaching upon two truths, truth relating to worldly convention and truth in terms of ultimate fruit. He who does not understand the distinction between these two truths does not understand the profound truth of the massage of the Buddha. Without relying upon the conventional truth ultimate fruit isn't taught. Without understanding the ultimate truth nirvana isn't attained (Kalupahana, 1983: 331-333).

These concepts, paramārtha and samvriti can be found with suffixes namely sacca (truth), vacana (term), desanā (exposition) in Pali Buddhism. For samivriti it has been utilized as conventional truth (vohāra-sacca), or commonly accepted truth (sammuti-sacca). Considering the language of the Buddha he utilized it occasionally sometimes conventional way and sometimes philosophical way. As we consider the Atta vagga of the Dhammapada of the Khuddakanikāya the concept of individual as conventional truth is accepted but not as ultimate truth. The expressions in the Sutta pitaka such as man, woman, person are conventional sense but expressions deals with aggregates, elements, sense-bases are basic factors but they also can again divide. Theravadins prefer to interpret Sutta pitaka as conventional exposition and Abhidhamma Pitaka as ultimate exposition. In the earliest account of the Pali Buddhism this can be seen under explicit or direct meaning (nātatha) and implicit or indirect meaning (neyyattha). "One who explains a discourse whose meaning requires interpretation as a discourse whose meaning is explicit, and one who explains a discourse whose meaning is explicit as a discourse whose meaning require interpretation" (Bodhi, 2012: 151).

Consequently, the roots of the Nāgārjuna's expressions on conventional and ultimate truths can be found in the early Buddhist discourses. Further, it has paid sufficient attention in Theravada Abhidhamma but obviously space does not permit a treatment of this subject here.

Chariot, person, monks etc. are conventionally true but they are not true by ultimate sense. Once Bhikkhuni Vajirā was at the Blind Men's Grove for day's abiding Mara, the Evil One and asked some questions which are commonly raised as:

By whom has this being been created?

Where is the maker of this being?

Where has the being arisen?

Where does the being cease?

The answer given by Bhikkhuni Vajir? was as follows. Just as with an assemble of parts,
The word 'chariot' is used,

So, then aggregates exist,

There is a convention of a being.

It is only suffering that comes to be,

Suffering that stands and falls away.

Nothing but suffering comes to be,

Nothing but suffering ceases (Bodhi, 2000: 551,552).

This explanation has also proved that there is no being apart form name and form and if there are causes then it can be seen the effect or result.

\section{Emptiness and Dependent Origination}

The next point which is utilized to refute rivals' argument is the concept of emptiness (śūnyatā) one of the most misinterpreted and misunderstood in later Buddhist philosophy. According to Sūnyatāvādins each phenomena is lack of inherent nature. Thus, one dharma cannot ultimately be distinguished from another because of the sameness of dharmas. Their sheared nature is emptiness but there are no ultimate basis and substance like the Brahman of the Upanișads (Harvey, 1990: 99). This concept directly mingles with the notion of no-self depicted in early Buddhism. Since this term as identified as nothingness many interpreters think that this is a new concept that was introduced by Nāgārjuna and popularly likes to say he is a Mahayana philosopher. It seems a great mistake was made by some interpreters. "If Buddhaghosa was to be considered the model of a Theravādins and Candrakīti or Śāntideva were to be looked upon as ideal Mahāyānists, neither the Buddha, nor Moggalīputtatissa, nor Nāgārjuna would fit into their shoes" (Kalupahana, 1983: ix). The examination of Noble Truths investigates emptiness is nothing but dependent origination, the theoretical foundation of early Buddhist teachings. The Mūlamadhyamakakārikā expresses "We state whatever is dependent arising, that is emptiness. That is dependent upon convention. That itself is the middle path (Yah pratityasamutpādah śūnyatām tām pracakṣmahe; sā prajcaptirupādāya pratipatsaiva madhyamāh. (Kalupahana, 1983: 339).

Since dependent origination is emptiness there isn't any argument of the authenticity of the early Buddhist relevance with Madhyamaka philosophy which was precisely expressed by Nāgārjuna. This explanation is similar to the Kaccāyanagotta sutta explanations in the Samyuttanikāya and many other discourses of the Pali Canon. "This world, for the most part depends upon a duality upon the notion of existence (atthitā) and the notion of non-existence (natthitā). But for one who sees the origin of the world as it really is with correct wisdom, there isn't notion of non-existence in regard to the world. And for one who sees the cessation of the world as it really is with correct wisdom, there is no notion of existence in regard to the world... All exists is one extreme. All does not exist is the second extreme. Without veering towards either of these extremes, the Tathāgata teaches the Dhamma by the middle: with ignorance as condition, volitional formations; with volitional formations as condition, consciousness... Such is the origin of this whole mass of suffering. But with the remainderless fading away and cessation of ignorance comes cessation of volitional formations; with the cessation of volitional formations, cessation of consciousness... Such is the cessation of this whole mass of suffering" (Bodhi, 2000: 544-545).

In brief, teachings of the Buddha has one taste that is nibbāna and Buddha used two types of methods for elucidation to his followers namely analysis and synthesis 
which helped not to be a part of two streams contemporary to him. Five aggregates, six bases, eight elements, twelve faculties and eighteen elements represent the former and these teachings precisely utilized for refutation the notion of eternalism (sassatavāda). Dependent origination, four noble truths, and theory of kamma represent the later and are utilized to refute nihilism (ucchedavāda). It does not mean that dependent origination was taught only for refutation of nihilism because it will be supportive to refute both eternalism and nihilism. Therefore, Buddhist ultimate reality, nibbāna cannot be achieved through these theories because the practical path was self-mortification (attakilamathānuyoga) for the former and self-indulgence ( $k a \bar{m} a-$ sukhallikānuyoga) that of later. The Buddha refuted those theories and practices, then, introduced the dependent origination (pațiccasamuppādam passati ) as his theory and the middle path (majjhimāpatipadā) as its practice.

This term has three parts; having depended (paticca), a right (sam) and arising (uppāda). Understanding the dependent origination understands the Dhamma. Selfsame manner understanding the Dhamma understands the dependent origination (Trenckner, 1979: 191). Once venerable Ānanda said that dependent origination is easy to understand and then the Buddha's answer was "Do not say that Ananda, Do not say that. This dependent origination is profound and appears profound. It is through not understanding, not penetrating, this doctrine that this generation has become like a tangled ball of string, covered as with a blight, tangled like coarse grass, unable to pass beyond states of woe, the ill destiny, ruin and the round of birth and death" (Walshe, 1995: 223). The relationship of cause and effect prove that there isn't anything that can consider as permanent in the ultimate sense.

All the basic teachings in early Buddhism are meaningful with the standpoint of dependent arising. The dependent origination is confirmed blamelessness of the notion of anatta (no-self), the last of the three characteristics of existence (ti-lakkhana) while refuting the self in this very life or circle of birth and death. It teaches that neither within this body nor outside can be found anything which can be considered as perpetual, permanent, eternal, unchanging phenomena. One of the most famous terms utilized to introduce the Buddha is anatavādī, teacher of impersonality. He has emphasized that there is no ego entity within or without the process. When Ānanda asked the Buddha in what sense the world is empty and the Buddha's answer was 'it is empty of self'. Then Ānanda asked again what the empty of self is and what belongs to self? The eye is empty of self and of what belongs to self. Forms are empty of self and what belongs to self... thus empty is the world, the Buddha replied (Bodhi, 2000: 1164; Feer, 1990: 54).

Traditional interpretations like to highlight that nonselfness of dharmas (dharmanairātmya) is one of the new findings in Perfection of Wisdom School, one of foremost point in Mahāyāna Buddhism while emphasizing Sarvātivādins as a group who teaches only non-selfness of persons (pudgalanairātmya) (Harvey, 1990: 97). Early Buddhist discourses clearly pointed out that all formations are subject to suffering but the expression of the last point anatta says all things are non-self. Therefore, these statements prove that not only conditioned but also unconditioned elements are no-self (Narada, 1993: 224).

The Simile of the raft explains how finally enlightened should behave towards the Dhamma. The Buddha compared his teaching to a raft to be used to cross a river but not to carry it afterwards. If a person who used a raft to cross a river and carry it afterwards on his shoulder thinking that the raft was very helpful to him, such a person isn't doing the right thing to the raft. Once crossed over one should haul it onto dry land or set it adrift in the water. The raft is only for crossing over and not to be carried over. In the same manner, the Dhamma is for crossing over the samisāra, not to carry over. The Buddha concluded his raftsimile in the following words: "Bhikkhus, when you know the Dhamma to be similar to a raft, you should abandon even the teachings, how much more so things contrary to the teachings (bhikkhave kullupamam mayā dhammo desito nittharanatthāya no gahanatthāya. Kullupamam vo bhikkhave ajānantehi dhammā pi vo pahātabbā, pageva adhammā) (Nanamoli \& Bodhi, 2009: 228-229; Trenckner, 1979: 132-134). If we read the raft should be thrown away after crossing a river it seems somewhat selfish. Nevertheless one who crossed a river can haul it onto dry land or set it adrift in the water and it will be beneficial for others who would like to cross a river. Thus, arahants attempting to protect the dhamma isn't merged with desire but with kindness towards the world. Finally, it says that not only dhamma but also adhamma should be abandoned. "This, however, isn't an invitation to moral nihilism, but a warning that even attachment to the noble teachings is an obstacle to progress. What is contrary to the teaching, adhamma would include the moral laxity that the bhikkhu Aritțha advocated" (Nanamoli \& Bodhi, 2009: 1205).

Therefore, teaching anatta is nothing but the confirmation of the dependent origination. The Discourse on the Characteristic of No-self (Anattalakkhana Sutta), the second discourse of the Buddha after his attaining to Buddha-hood is based on the contemplation of no-self (anattānupassanā) guides to the emptiness liberation (succatavimokkha) (Feer 1975: 66; Bodhi 2000: 901-903). It should be stated here that in this discourse the term succata (śūnyatā in Sanskrit) which was more popular among Madhyamaka philosophers is very clearly mentioned.

The Kamma theory is also directly connected with the teaching of dependent origination. While explaining the general theory of kamma it shows the relationship with cause and effect.

"Whatever sort of seed is sown,

That is the sort of fruit one reaps:

The doer of good reaps good;

The doer of evil reaps evil.

By you, dear, has the seed been sown;

Thus you will experience the fruit" (Feer, 1991: 227; Bodhi, 2000: 328).

The cause and condition for people are seen to be short-lived and long-lived, sickly and healthy, ugly and beautiful, uninfluential and influential, poor and wealthy, low-born and high-born, stupid and wise is also expressed focusing on general theory of kamma. Killing living beings and living in a violent way is the reason for short-living and abstaining from killing living beings and living gently and kindly is the reason for long-living. Injuring beings makes sick and not injuring make healthy, anger and terrible character make ugly and no anger and irritable make beautiful. In this manner cause of the effects has been explained (Nanamoli \& Bodhi, 2009: 1053-1057). This is the general examination on Buddhist kamma it is called the Shorter Exposition of Action, Cullakammavibhanga. The explanation on the Greater Exposition of Action, Mahākammavibhańga (Nanamoli \& Bodhi, 2009: 1058- 
1065) represents the advance level of the concept. This expresses that Buddhist kamma is nothing but cause and effect, in other words if there is/are no cause/s then there cannot be risen effect/s.

The statement of the Visuddhimagga, the most outstanding text for the Theravada notion highlights more the concept of emptiness with its ethical basement. Mere suffering exists but no sufferer is found. Deeds are there but there is no doer. There is nibbāna but there is no man that enters in. There is the path but there is no traveler on it is seen. (Davids, 1975: 602, Nanamoli 2010: 603; 627).

Even though Buddhist standpoint emphasizes no-self with the ultimate sense it demonstrates on former and after life as a principle. Special knowledge of recollection of one's former abode and knowledge of vanishing and reappearing of beings living are good examples for that and many of the discourses Buddhism discusses about the circle of birth and death. This notion of next life is also centered on the theory of dependent origination. There were five causes in the past and now there is a fivefold fruit. There are five causes now as well and in the future fivefold fruit. The twelvefold dependent origination is expressed in this manner. Following chart will express clearly (Nanamoli, 2010: 601).

Further, Nāgārjuna says that if all this is non-empty (aśūnyami) there exists no uprising and ceasing. These imply the non-existence of the four noble truths (yadi aśūnyam idam sarvam - udayo nāsti na vyayaḥ; caturnām āryasatyānā - mabhāvaste prasajyate. Kalupahana 342). Therefore, he does not refute four noble truths because that is uprising and ceasing of suffering. That is also synonymous for dependent origination.

Misunderstanding of emptiness ruins a person of meager intelligence like a snake that is wrongly grasped and knowledge that is wrongly cultivated. Since the wrong view held by Arittha, "as I understand the Dhamma taught by the Buddha, those things called obstructions by the Buddha are not able to obstruct one who engages in them" the Buddha demonstrated with the simile of the snake. Some misguided men (mogha-purisa, empty man) learn the Dhamma namely, discourses (sutta), stanzas (geyya), expositions (veyyāakaraña), verses ( $g a \bar{t} h a)$, exclamations (udāna), sayings (itivuttaka), birth stories (jātaka), marvels (abbhutadhamma), and answers to questions (vedalla) but having learned it they do not examine the meaning of those teachings with wisdom, Not examining the Dhammas with wisdom they do not gain a reflexive acceptance. They learn the Dhamma only for the sake of criticizing others and for winning debates. They do not experience the good for the sake of which they learnt the Dhamma. Those teachings being wrongly grasped by them conduce to their harm and suffering for a long time (Nanamoli and Bodhi, 2000: 227).

\section{Self-nature}

There is another point that needs clarification here. It is self-nature, the last point can be found in this chapter. Self-nature isn't something that comes and goes and it isn't an occurrence but it is forever. Nāgārjuna has expressed baseless nature of the notion of self-nature from $22^{\text {nd }}$ to $38^{\text {th }}$ verses in detail. He who believes self-nature there would not appear arising of suffering and ceasing of suffering. At the same time it isn't possible to discuss about cultivating the path and consequently without practice how can one attain nirvāna. If it is so, understanding (parijcā), relinquishing (prahānna), realizing (sākșātkaraṇa) and cultivating (bhāvita) are also impossible. If a certain great- being who fulfils dharmas relevance to be attained Buddhahood he could not attain it because of self-nature. This explanation is also based on emptiness because all things are empty because of no intrinsic nature (svabhāva). The concept of self-nature cannot be seen in early Buddhist discourses because it always emphasizes dependent arising. Not only in early Buddhism but also in any books of the Abhidhamma pitaka cannot be found svabhāva in the sense of dhamma. However, exegesis of Abhidhamma expresses in the sense of dhamma (Karunadasa, 2015: 35).

\section{Conclusion}

While doing his explanations through Examination of Noble Truths, Āryasatyaparīkșā Nāgārjuna taught his great philosophical point, emptiness. Since the Mūlamadhyamakakārikā does not exist as a separate chapter for emptiness this is the longest and most significant chapter on his great philosophical notion. Nāgārjuna has utilized three points to prove the concept of emptiness (śūnyatā, súnyatva) namely double truths, dependent origination and self-nature. Two points are admired and the last point selfnature has been refuted. In point of fact, what Nāgārjuna did was highlighting the most fundamental and theoretical point which can be connected with all the teachings of the Buddha. Though it was discussed in many early Buddhist discourses his philosophical explanations attracted many Buddhist scholars and sometimes they had generated obsession with regard to emptiness. Early Buddhist explanations related to this chapter proves that Nāgārjuna was a well versed monk on early Buddhism, even its similes, and launched his great wisdom based on contemporary issues. However, not having considered Nāgārjiuna's own explanation 'whatever is dependent origination that is emptiness' later on this philosophy was merged with nihilistic interpretations.

\section{REFERENCES}

Bodhi, Bhikkhu (1999). A Comprehensive Manual of Abhidhamma, Sri Lanka, Kandy: Buddhist Publication Society.

Bodhi, Bhikkhu (2000). The Connected Discourses of the Buddha A New Translation of Samyuttanikāya, Boston: Wisdom Publication.

Bodhi, Bhikkhu (2012). The Numerical Discourses of the Buddha a new Translation of the Amguttaranikāya, Boston: Wisdom Publications.

C.A.F. Rhys, Davids, Ed. (1975). Visuddhimagga of Buddhaghosa, London: The Pali Text Society.

Feer, Leon M., Ed. (1975). Samyuttanikāya Vol. III., London: Pāli Text Society.

Feer, Leon M., Ed. (1991). Samyuttanikāya Vol. I., Oxford: Pāli Text Society.

Hardy, E. (1976). Amiguttaranikāya Part IV \& V, London: Pāli Text Society.

Harvey, Peter (1990). An Introduction to Buddhism Teachings, History and Practices, India: Munshiram Manoharalal Publishers Pvt. Ltd.

Kalupahana, David J. (1995). Nāgārjuna's Moral Philosophy and Sinhala Buddhism, Kelaniya: University of Kelaniya, Postgraduate institute of Pali and Buddhist Studies.

Kalupahana, David J. (1996). Mūlamadhyamakakārikā of Nagarjuna the Philosophy of the Middle Way, Delhi: Motilal Banarsidass Publishers.

Karunadasa, Y. (2015). The Theravada Abhidhamma its Inquiry into the Nature of Conditioned Reality, Sri Lanka, Kandy: Buddhist Publication Society. 
Nanayakkara, Sanath (2016). "Shift of Emphasis from Anatta to Śūnya". In Tilakaratne, Asanga and others, Ed. Buddhist Philosophy, History and Culture, Selected Essays of Sanath Nanayakkara, Colombo 10: S. Godage and Brothers.

Narada, Mahatheara (1979). A Manual of Abhidhamma Being Abhidhammatthasarigaha, Kuala Lumpur, Malaysia: The Buddhist Missionary Society.

Narada, Mahatheara (1993). The Dhammapada, Thaiwan: The Buddha Educational Foundation.

Nyanatiloka, Ven. (1988). Buddhist Dictionary Manual of Buddhist Terms and Doctrines, Kandy: Buddhist Publication Society.

Siderits, Mark and Katsura, Shōryū (2013). Nāgārjuna's Middle Way Mūlamadhyamakakārikā, Boston: Wisdom Publication.

Siri, Sivali, Ed. (1985). The Dhammapada, Colombo 10: Samayawardhana Publishers.
Tilakaratne, Asanga (2001). Sūnyatāvādayehi Darśnaya ha Caranaya: Nāgārjuna Pādayange Mūlamadhyamakakārikāvehi Pela, Sinhala Parivartanaya hā Artha Vivaranaya, Nugegoda: Tivira Prakasana.

Trenckner, V., Ed. (1979). Majjhimanikāya Vol. I, Oxford: The Pali text society.

Walshe Maurice, Tr. (1995). The Long Discourses of the Buddha, A translation of the Dighanikāya, Boston: wisdom publications.

Cānamoli, Bhikkhu \& Bodhi, Bhikkhu Tr. (1995). The Middle Length Discourses of the Buddha A new Translation of the Majjhimanikāya, Sri Lanka, Kandy: Buddhist Publication Society.

Cānamoli, Bhikkhu Tr. (2012). The Path of Purification Visuddhimagga, Sri Lanka, Kandy: Buddhist Publication Society.

Вімал Хеваманейж,

Університет Коломбо (м. Коломбо, Шрі-Ланка)

e-mail:wimal@bs.cmb.ac.lk, ORCID 0000-0003-2886-7637

\section{ДОСЛІДЖЕННЯ БЛАГОРОДНИХ ІСТИН У МУЛАМАДХ'ЯМАКАКАРІКАРІ ТА ЇХ ЗНАЧЕННЯ ДЛЯ РАННЬОГО БУДДИЗМУ}

Стаття присвячена малодослідженій сторінці історії ранньої буддистської філософії, а саме - формуванню вчення про Благородні Істини в творчості Наґарджуни - відомого індійського філософа II-III ст. н.е., який вважається засновником школи мадхьямаки філософії Махаяни. Важливим джерелом цього напрямку є Муламадхьямакакаріка, або "Фундаментальні вірши про Серединний Шлях", укладачем якого був Наґарджуна. Ця збірка складається 327 розділів та вважається базовим текстом Махаяни, що мав величезний вплив на подальшу еволюцію філософії буддизму в Індії, Тибеті та Східній Азії. В статті аналізується 24-й розділ "Вивчення благородних істин", який складається 340 віршів, присвячених різним питанням, дотичним до умов осягнення істини. Метою даної статті є аналіз предметних питань 24 розділу в контексті розгортання ранньобуддистського філософського дискурсу. Погляди Наґарджуни на шляхи досягнення істини порівнюються з інтерпретаціями сучасних істориків буддистської філософії: Д. Калупахана, А. Тілакаратне, М. Сідерітса, Ш. Кацури та ін. Наведена компаративістика дозволяє більш повно усвідомити процес становлення Махаяни, а також надати змістовне тлумачення того, що таке шуньята.

Ключові слова: буддистська фрілософрія; Нагарджуна; Муламадхьямакакаріка; Махаяна; шуньята.

(C) Wimal Hewamanage

Надійшла до редакції: 17.01.2020

Прийнята до друку: 06.02.2020 